Max Koch

\title{
THE NATURALIZATION OF GROWTH: MARX, THE REGULATION APPROACH AND BOURDIEU
}

Draft 09/05/2017

\section{INTRODUCTION}

200 years of capitalist growth including Industrial Revolution and Great Acceleration after World War II (Pichler et al., 2017) have had the result that thresholds for specific biophysical processes such as climate, biodiversity and nitrogen cycle are being approached or crossed (Steffen et al., 2015). Attempts to absolutely decouple GDP growth per capita from ecological footprints of production and consumption and carbon emissions on a global scale have hitherto failed (Fritz and Koch, 2016). In response, significant theoretical efforts have been made to understand how socially inclusive and environmentally sustainable development could evolve without economic growth (D’Alisa et al., 2014; Koch and Mont, 2016; Spash, 2017). However, a recent historical treatise on the 'hegemony of growth' comes to the conclusion that 'growth is deeply embedded within social relations, modern industrial society, and capitalist modes of production.' (Schmelzer, 2016: 352) To systematically reflect this embeddedness Brand (2016: 508) recently postulated in Environmental Values to focus 'on the structured and structuring "whole" of manifold societal relations' as well as on 'the mechanisms that create those interlinkages and society's ability to deal with contradictions and might give such relations certain continuity over time'. Such a 'historical-materialist perspective' (Brand, 2016) also promises to overcome the 'heavy emphasis on autonomy of the individual' (Spash, 2016: 253), from which much current environmental theorizing suffers, since it considers those social structures that influence individual action despite the fact that individuals are normally unaware of this. 
This paper scrutinizes the extent to which economic growth is inherent to capitalist production and consumption relations and how this is reflected in people's minds and bodies. The background assumption is that the hegemony of a discourse increases with the extent to which its socio-historical genesis and character is hidden and perceived as natural and without alternative (Gramsci, 1971). This resonates with the Castoridian perspective taken by Asara et al. (2013: 232) which defines 'domination' as the 'result of the naturalisation of the instituted and of the corresponding aproblematic assumption of the interiorisation of social norms.' Indeed, what Daly (1972) first called the 'growth paradigm' is today almost universally accepted. It predicates that economic growth is 'good, imperative, essentially limitless, and the principal remedy for a litany of social problems' (Dale, 2012a). Despite the fact that economic growth played an at best minor role before the $1820 \mathrm{~s}$, when it started to accelerate in the context of the Industrial Revolution ${ }^{1}$, influential think-tanks such as the OECD (Schmelzer, 2016), policy makers and the wider public came to see growth as the optimal context to provide prosperity for all. Not only companies, whose profit rates are thought to increase with GDP, appear to benefit from economic growth but so do employees, whose real wages can grow in parallel with profits if the overall scale of production expands. The idea that it is 'worth it to work hard' both in educational and occupational career is a constant feature of people's day-to-day consciousness. The more one invests into one's career, the greater the rewards will be in terms of financial remuneration and consumption of material goods during 'leisure'. The paper first addresses core features of capitalist production and accumulation due to which economic growth comes across as the natural way of running the economy and why people, especially working people, are led to think that they benefit from growth if they make their contribution through work. Secondly, it asks whether the distortion

\footnotetext{
${ }^{1}$ Before that global economic activity had expanded by an average of $0.05 \%$ annually only, and this slight increase was largely due to slow augmentations in population (Maddison, 2007).
} 
of specific social issues into natural ones finds its continuation in the sphere of consumption and lifestyles. Are such cultural patterns - including the most exclusive ones which tend to be most ecologically harmful - perceived in their social origin or as natural varieties of taste about which one can do very little?

Theoretically, Brand (2016: 508) makes a compelling case for the usefulness of the 'historical-materialist perspective' and some of its core concepts for a critical theory of socialecological transformation. Similarly, I propose that growth-critical scholarship ${ }^{2}$, particularly in relation to understanding and analyzing the structural obstacles to degrowth, would benefit from a deepening of exchanges with the Marxian tradition and Bourdieusian sociology. The reference to Marx may sound controversial to some green scholars given his alleged 'Promethean' leanings (O'Connor, 1998) which would have brought him to have advocated the conquest of nature by man. Yet since the publication of O'Connor's book a range of publications have not only refuted this view but also developed Marx's original critique of economic growth and ecological theory (Foster, 2000; Burkett, 2009; Koch, 2012; Moore 2015; Kenney-Lazar and Kay, 2017). In addition, a number of authors opened up for an approximation between ecological Marxism and postgrowth approaches (Alvarez Lozano, 2012; Dale, 2012b; Koch, 2015). However, a potentially useful scholarly tradition within the Marxian tradition has hitherto not been applied to the understanding of the growth paradigm: that of ideology critique (for an overview, see Rehmann, 2007). Reflecting the fact that 'all science would be superfluous' (Marx, 2006: Chapter 48), if essential features of economic categories, social relations and their modes of appearance coincided, this paper first reviews how Marx theorized and explained the naturalization of core features of the capitalist mode of production, especially the growth imperative. The section will present the argument that,

\footnotetext{
${ }^{2}$ The broad term 'postgrowth' may unite liberal (Ferguson, 2016), Marxist and other variations of growth critique including degrowth. For an overview of growth-critical approaches see Büchs and Koch (2017: Chapter 4).
} 
corresponding to Marx's methodological 'rise from the abstract to the concrete' in Capital, there is what I am going to refer to as a 'stepladder of mystifications' due to which specifically capitalist economic categories and social relations appear as natural and eternal conditions of production per se. Emphasis will be placed on how Marx explains the huge amounts of ideological power that ideas such as 'growth', 'meritocracy' and 'social position as result of own achievements' have - even among social strata that may 'objectively' be regarded as not benefiting from the continuation of capitalist growth.

Consumption, by contrast, is constantly addressed by growth-critical scholars. What and how much we buy and consume directly affects our ecological footprint, since consumption patterns are normally bound to matter and energy transformations, which more often than not necessitate the burning of fossil fuels. Though this is fully considered especially in degrowth scholarship, Jonas and Littig (2015: 835) observe that somewhat moralistic pleas to 'responsible consumerism and corresponding choices' dominate the debate. Postgrowth approaches to consumption in general have not significantly come beyond adoptions of what Shove (2010) refers to as the 'ABC formula', where A stands for attitude, B for behavior, and C for choice. In such approaches, social inequality, power structures and the ways in which these are perceived are not systematically addressed, while the responsibility for sustainable consumption is shifted to individuals and private households (Spash, 2016). I apply a combination of the Regulation approach and Bourdieusian sociology to reflect that consumption-oriented purchase decisions are neither 'spontaneous' nor 'individual' but influenced by structural factors such as social class of which neither consumers nor consumption industries are normally aware. Specifically, I will review Bourdieu's sociology in terms of its ability to provide an analysis of the social genesis of the variants of 
consumption and taste - many of which are ecologically unsustainable - and how this process is perceived by the agents themselves.

The paper proceeds as follows: The next two sections address the hegemony of the growth paradigm in relation to the sphere of production by revisiting Marx's critique of political economy with emphasis on the 'stepladder of mystifications'. Section 4 is dedicated to the sphere of consumption and critically reviews the contribution of Bourdieu's sociology toward understanding the hegemony of the growth paradigm. The Regulation approach is used as an analytical bridge of the Marxian and Bourdieusian traditions and to provide an institutional and historical understanding of growth. The conclusion summarizes the argument in the perspective of overcoming the hegemony of capitalist growth.

\section{GROWTH AS CAPITAL ACCUMUMULATION}

Karl Marx witnessed an economy, where the Industrial Revolution had dramatically raised labour productivity and most labour products had taken the form of commodities, that is, they were produced for exchange operations on markets. Marx (1990: 138-162) develops the structural imperative of capitalist economies to expand in scale and grow in monetary terms from the logic of exchange relations and, specifically, the money form. He compares two kinds of exchange or 'metamorphoses' of commodity and money. In the first one - commoditymoney-commodity - the purpose of the exchange is qualitative. A holder of a commodity exchanges it for its money equivalent, then, he or she buys another commodity for his or her own use: 'selling in order to buy' (Marx, 1990: 247). In this exchange, the role of money is that of a measure and store of value as well as that of a legal tender. Then Marx (1990: 227) argues that with the first development of the circulation of commodities, 'there also develops the necessity, and the passionate desire to hold fast the product of the first metamorphosis': money 
serves here as the general and ultimate expression of the wealth available in a society or as capital that potentially leads to profit and bears interest. The purpose of the second metamorphosis - money-commodity-money - can only be a quantitative one, since there is no qualitative difference between its origin and result: the production of more money compared to the original amount. Profits can be made due to the fact that a commodity is available for sale that has the use value of creating exchange value and can be used longer than the time period that represents the cost of its own reproduction: labour power. Producers - as wage earners are largely separated from their means of subsistence and production and have no alternative but to offer the only commodity at their disposal on 'labour markets'. Likewise, the other 'factors of production' - land, raw materials, fuels, auxiliaries etc. - can be purchased on separate markets, and it is only through the intermediation of employers, who hold the necessary capital, that the various elements of the production process come together. Moore (2015) refers to the structural pre-conditions necessary for long-term capital accumulation in terms of 'four cheaps': Labour power, food, energy and raw materials must be available at relatively low prices for a longue durée of capitalist growth to evolve.

Marx (1990: 429-438) discusses the tendency of capitalist economies to expand in scale - and thereby the 'growth imperative' - at the example of 'relative surplus value'. The profitability of a company can not only be improved by increasing the working hours of the wage-earners ('absolute surplus value') but also by shortening the part of their working day that is necessary for the workers' physical and social reproduction. Marx explains a reduction in the price of labour power through increases in productivity in those branches of production that are part of the consumption patterns of the wage-earners. However, he also stresses that the realization of such relative surplus will face an immanent contradiction: individual owners of capital are permanently motivated to optimize the technological and organizational basis of the work 
process in order to be one step ahead of their competitors. This is normally carried out by a substitution of workers by machinery or by an improved organization of the internal division of labour. The employers whose productivity level is above average can thus achieve extra profit since they are able to sell their commodities at prices below the normal level. Yet such an improvement of production methods tends towards generalization, and the extra profit moves towards zero, since competing companies have no choice but to copy the new methods or even to improve upon them. As the new productivity level gradually becomes the new standard, a given quantity of commodities is now produced with less labour effort than previously - and the price of a single commodity decreases as a result. Marx concludes that, on the one hand, the rate of surplus of the employed workers increases; on the other hand, however, the absolute volume or mass of surplus value (and, other conditions being equal, the mass of profit) decreases since fewer workers are needed to produce a given amount of commodities than before. In order to keep the volume of profit stable, despite this dilemma, there is no alternative but to expand the overall scale of production through the reinvestment of previous profit, in other words 'accumulation' of capital.

Following Marx, Moore (2015: 93-94) observes that capitalist accumulation tends to increase the ratio of constant to variable capital, and, within constant capital, the ratio of fixed (what outlasts a given production cycle, for example buildings, machinery) to circulating constant capital (the raw materials and energy used up in the cycle). Or, more simply, over time proportionally more capital is invested in machinery than in raw materials, energy and labour power. Long cycles of accumulation or 'golden eras' of capitalist growth result in an 'overproduction of machinery' and an 'underproduction of raw materials', reflected in 'overcapacity' and 'rising raw material prices'. The transition from one growth period to the next has historically been accompanied by scientific revolutions but also new imperialisms. 
Based on earlier feminist and post-colonial scholarship (Mies, 1998; Fraser, 2014), Moore (2015: 95) analyzes the interaction between the exploitation of wage labourers and the appropriation of human and non-human natures in the production of value. ${ }^{3}$ Though unpaid work, energy and raw materials are not commodified, they are nevertheless appropriated complementing the exploitation of labour power. Hence, commodification needs to be 'kept in check' for accumulation to proceed. Since long-term accumulation and economic growth is dependent on the provision of the 'four cheaps', crises have historically been overcome by 'world-ecological revolutions that create opportunities for windfall profits' through the provision of 'new historical natures' and the corresponding expansion of (commodity) frontiers through 'waves of enclosure, imperial expansion, scientific practice, and dispossesionary movements' (Moore, 2015: 96). ${ }^{4}$

Marx (1990: Part IV) moves on to discuss at the historical example of England the advancement of the division of labour and how the work process became successively independent from the individual crafts of workers through the systematic application of natural forces and the natural sciences. Once the work process had an industrial foundation, the subjugation of nature under capital became more complete. Expanding scales of production and economic growth coincided with greater amounts of throughput of raw materials and auxiliary substances, especially in the form of fossil fuels as well as of available energy. Rising demand for raw materials and available energy normally leads to rising prices, for example, for crude oil, creating incentives for individual companies to recycle and to use a given quantity of materials or fuels in more efficient ways. Yet progress in the efficiency of

\footnotetext{
${ }^{3}$ Collard and Dempsey (2017: 79) offer a more differentiated typology of 'human and nonhuman lives and bodies in relation to capitalist value'.

${ }^{4}$ Moore (2015: 116) derives from the distinction of 'historical natures' and 'nature in general' a somewhat unfortunate critique of 'Green Thought' and related empirical concepts such as the ecological footprint. In emphasizing ecological issues where they become problems for capitalist accumulation he tends to downplay them where these threaten to disrupt the Earth System as a whole.
} 
raw and auxiliary materials does not fundamentally alter the link between the expansion of the scale of production and the increase in the material and energy throughput, a phenomenon that had been already observed by Jevons (1865). Greater efficiency in the use of a fossil energy source leads to an increase in demand for energy - not to a decrease - and in fact constitutes a necessary precondition for further capital expansion and economic growth. The second and third volumes of Capital consider that capital does not only exist in its productive, that is, value-producing, form but also in unproductive forms, like money and commodity capital. While alternating between these three forms, competition forces individual companies to reduce the two unproductive functions of the capital cycle and, hence, to speed up the overall turnover process as much as possible. Whereas the matter and energy transformation processes associated with all work processes have an irreversible and linear character, the structural imperative towards increasingly rapid turnover cycles, is characterized by and a tendency towards temporal and geographic 'simultaneity' or 'time-space compression' (Harvey, 1990).

\section{THE STEPLADDER OF MYSTIFICATIONS}

Marx not only identifies the structural imperatives inherent to capitalist society that result in expanded capital valorization and, hence, economic growth. He also analyzes the corresponding social relations and modes of consciousness as 'socially valid' - thus objective - 'forms of thought' (Marx, 1990: Chapter 3). Or, in other words, Marx is not concerned with the 'mystifications in the brain, but rather with the objective inversions in capitalism, by which exchange value rules over use value, abstract labour over concrete labour, and private capitalist profit rules over people's lives.' (Rehmann, 2015) In order to bring those social structures to the foreground, that are normally hidden from our minds, Marx (1973: 147) methodologically 
advocates a successive rise from abstract to concrete economic categories and associated social relations to which particular forms of consciousness correspond. For example, the analysis of commodity and money exchanges - the 'simple circulation' - reveals a specific type of consciousness that Marx (1990: Chapter 6) characterizes as 'Eden of the innate rights of man. It is the exclusive realm of Freedom, Equality, Property and Bentham.' However, when also considering production and accumulation relations this perception is fundamentally altered and complemented by the experience of inequality and exploitation. The more the analysis moves up towards more concrete levels of abstraction, the more distorted are the forms in which the participating individuals make sense of their socio-economic context. Following Herkommer (1985), who used the German term Stufenleiter der Mystifikation, I refer to this process as 'stepladder of mystifications'.

For Marx the 'most abstract concrete' was the commodity, characterized by a 'twofold character'. Both are interdependent in that without exchange value, commodities would not be produced for sale, and without use value, they would not be purchased. By no means follows from this that the purpose of labouring to produce articles of consumption is their exchange upon the market. But to the economic agents the commodity's characteristic of abstractly embodying exchange value appears just as natural as its concrete use value. ${ }^{5}$ This is particularly obvious in the commodities that were historically used as money (gold and silver), which, on top of their other use values, seemed to have the natural quality to define societal wealth as 'general equivalent'. Marx describes the exchange processes of commodities and money as a 'simple' version of the total valorization process of capital insofar it merely mediates the productive processes that are themselves not objects of analysis. From the perspective of mere

\footnotetext{
${ }^{5}$ Marx uses the term 'fetishism', which was first developed by Portuguese missionaries in Africa to portray what they considered to be 'primitive' tribes. Just as these tribes bowed to their own artifacts, the supposedly 'enlightened' economic subjects are unaware of the specifically historic conditions under which labour products take commodity form.
} 
exchange relations it appears to be down to the subjective preferences of commodity proprietors to determine which labour products are to be exchanged. On the question of how 'did the owner become possessed of it (the original capital)' the answer of the 'spokesmen of Political Economy' is clear-cut: 'By his own labour and that of his forefathers' - a 'supposition' that, according to Marx (1990: 728), 'appears the only one consonant with the laws of the production of commodities.' If current possessions of wealth in the form of commodities and money presuppose previous own work, a disciplined work ethic seems to be a rational individual strategy to participate in societal wealth. The more one works the greater will be one's piece of the pie. This perception of equivalence and equality is amplified by the fact that individuals must 'recognize one another reciprocally as proprietors' (Marx, 1973: 243) in order to exchange commodities. Since appropriating commodities through the use of force is neither legal nor legitimate, the sphere of circulation presupposes the juridical and political equality of the exchange parties.

At the level of production relations, increasing productivity seems to be a natural feature of capital and not an outcome of the socialized form of work. It is through the intermediation of employers that labour power is combined with the land, raw materials, fuels etc. so that new commodities can result. This 'capital fetish' is accompanied and amplified by a wage fetish according to which all work appears to be compensated (Marx, 1990: Chapter 19). In the wage form the difference between necessary and surplus labour has disappeared so that all labour that the worker puts in during the working day seems to be remunerated. Marx regards this as the structural basis for all further mystifications: industrial profit as well as its sub-categories (rents and interests) must then have other sources than surplus labour and seem to naturally originate from different functional economic roles. In the 'trinitary formula', where capital generates profit, land generates rent and labour generates wage, all societal specificity is reified and 
naturalized. In these 'estranged and irrational forms' - an 'enchanted, perverted, topsy-turvy world, in which Monsieur le Capital and Madame la Terre do their ghost-walking as social characters and at the same time as mere things' - the economic agents feel themselves 'completely at home' (Marx, 2006, Chapter 48). The reversal of historically specific economic categories and social relations into natural forms produces 'spontaneous consent' (Rehmann, 2007: 214).

At the end of Capital, Volume 1, Marx analyzes the valorization process of capital over time. 'Accumulation' means that employers do not consume all the profit they produced during the preceding cycle of production, but instead that they reinvest at least some of it so that it functions as additional capital, alongside the original capital. In relation to the former, Marx (1990: 728) observes that there is 'not one single atom of its value that does not owe its existence to unpaid labour.' Far from being a result of previous own work, the 'ownership of past unpaid labour is thenceforth the sole condition for the appropriation of living unpaid labour on a constantly increasing scale. The more the capitalist has accumulated, the more is he able to accumulate'. Marx (1990: 729) concludes that the 'laws of appropriation or of private property', which are based on the 'production and circulation of commodities, become by their own inner and inexorable dialectic changed into their very opposite.' The original exchange of equivalents turns out to be a 'mere semblance belonging only to the process of circulation', a 'mere form, which is alien to the content of the transaction itself, and merely mystifies it.' (Marx, 1990: 729-730) This formal exchange only introduces the real exploitative relationship between capital and labour the essence of which is the 'constant appropriation by the capitalist, without equivalent, of a portion of the labour of others ...' (Marx, 1990: 330). 
In summary, the exclusive focus on markets and exchange relations suggests that 'rights of property' are 'based on a man's own labour', since at that level of abstraction 'only commodity-owners with equal rights' confront each other, and the sole means by which one can 'become possessed of the commodities of others', is by 'alienating' one's 'own commodities' (Marx, 1990: 730). Due to the logic of equivalence that structures market transactions and the illusion that commodity possession and wealth stem from own work, individual contributions towards GDP growth via own work efforts must appear as rational economic strategies. When considering also the spheres of production and accumulation, however, 'property turns out to be the right, on the part of the capitalist, to appropriate the unpaid labour of others or its product, and the impossibility, on the part of the worker, of appropriating his own product. The separation of property from labour thus becomes the necessary consequence of a law that apparently originated in their identity.' (Marx, 1990: 730) Yet this transfer of surplus labour is hidden through the continuing distortion of specifically capitalist economic categories and social relations into objects and natural features along the stepladder of mystifications. Since all labour seems to be paid, profit must result from other sources, and capitalism appears to be the natural state of the economy.

\section{CONSUMPTION AS DISTINCTION}

If people's ability of imagining alternatives to growth-oriented capitalism is severely undermined by the social structures of the economy in which they act, we now examine whether the 'non-economic' sphere of consumption is shaped by similar patterns of conversion of social relations into characteristics of nature and things. A useful contribution to link analyses of production patterns to those of consumption has been tabled by the Regulation approach, which, at least in their Parisian version, maintains key insights of Marx's Critique of Political Economy such as 'modes of production' and 'social formations' and complemented 
these with 'intermediary concepts' ('accumulation regime' and 'mode of regulation'), which express the largely non-variable conditions of the agents involved in the relations of production and exchange, as well as the historical changes these relations undergo during different phases of capitalist growth (Boyer and Saillard, 2002; Koch, 2012). Such longues durées take the form of compatible commodity streams of production and consumption reproduced over a relatively long period of time. Accumulation regimes differ historically, for example, as to whether intensive forms dominated over extensive ones, export-oriented over import-oriented or vice versa. The focus on 'regulation' allows, in relation to ecological issues, to go 'beyond ecoMarxism' and its emphasis on the incompatibility of the 'capitalist mode of production and the preservation of the biosphere.' (Brand and Wissen, 2015: 512) In fact, regulation defuses these structural tensions and re-articulates them as a 'problem of capitalist development as a whole, by postponing hazardous negative consequences into the future or externalizing them across space' (Brand and Wissen, 2015: 512).

Accumulation regimes are associated with a specific industrial paradigm, a dominant principle of the division of labour, an energy regime as well as a corresponding 'mode of consumption'. Hence, consumption is not seen as an isolated or behavioral phenomenon, the result of autonomous individual choices, but in its social genesis and context, an 'organized set of activities, which - while predominantly private - became subject to a general logic of the reconstitution of energies expended in social practices and the preservation of abilities and attitudes implied by the social relations' (Aglietta, 1987: 154). Boyer (2008) and Koch (2006 and 2012) have demonstrated that the Regulation approach is compatible with Bourdieusian sociology. First, both research programmes set out from a critical evaluation of Marxian insights. ${ }^{6}$ Second, they share the basic hypothesis that 'life in society is made possible by the

\footnotetext{
${ }^{6}$ See Koch (1998) and Herkommer (2004) for detailed elaborations of the relationship of Marxism and Bourdieusian sociology. Similarities include above all the common position to understand the reproduction of
} 
way in which institutions are constructed, just as economic activity is organized by the mode of régulation.' (Boyer, 2008: 348) Hence, both object to the 'scholastic bias' (Bourdieu, 2005: 7) in economics or the tendency to construct increasingly abstract models, "which leads the scholar to project his thinking into the minds of the active agents and to see (his own representations) as underlying their practice'. Far from being an anthropological constant, the ascendancy of an aptitude for rational behavior in production and consumption is the result of long historical processes during which it has been inscribed in people's social and cognitive structures, practical patterns of thinking, perception and action. Third, regulationist research has turned to Bourdieu's concept of 'habitus' as an alternative to the theory of rational choice and a bridge between 'objective' social structures including patterns of inequality and consumption and allegedly 'subjective' lifestyles. As an internalized product of the social structures that conditioned it, habitus supplies one with a sensibility towards these and the possibilities they include and exclude. It is amor fati, supplying a sort of social orientation, by which the occupants of a given position in social space are guided towards socio-cultural practices adjusted to their properties, and towards the practices that befit the occupants of that position.

Bourdieu's sociology of consumption breaks with classical aesthetic theories. Kant had distinguished between 'reflective' and 'barbarian' tastes. According to Bourdieu, Kant had failed to recognize that tastes are socially conditioned and maintained by the dominant groups in order to enforce their distance or distinction from the sphere of material necessity and, hence, other societal groups. Understood as 'social necessity made second nature' (Bourdieu 1984: 476), taste therefore becomes an efficient weapon in the social struggle about generally desired

\footnotetext{
societal core structures largely as unintended side-effects of purposeful action. Differences include especially the notions of 'capital', which for Marx is an exploitative social relationship where the relative welfare of capital holders is causally linked to the relative poverty of those who don't, while Bourdieu (1986) uses the concept largely synonymously with resources and distinguishes between economic, cultural (subdivided in institutionalized and embodied forms), social and symbolic capital. Consequently, Bourdieu's class theory departs from Marx's so that all social actors become 'capitalists', differentiated only in relation to the volume and the structure of the capital they command.
} 
resources in that it defines and marks off the high from the low, the sacred from the profane, and the legitimate from the illegitimate in matters ranging from food and drink, cosmetics, and newspapers to art, music and literature. A break with the Kantian 'pure aesthetic' then consists of a thorough sociological inquiry into the social genesis of the variants of taste. Rather than assuming a direct link between economic structure and cultural practices, Bourdieu hypothesizes empirical 'homology' between two relatively autonomous social spaces - a hypothesis requiring empirical verification.

The cultural space is subdivided into a range of fields including cinema, theater, art and food. These fields are themselves constituted by specific power relations, strategies and interests in which an actor's coordinates are determined by both the amount and the composition of 'capital'. In the cultural sphere different class cultures develop different tastes so that even the perception and appropriation of one and the same cultural product by different classes follows different social patterns and yields different amounts of symbolic capital. In Distinction, Bourdieu empirically demonstrates correspondence between socio-economic positions, education levels and tastes. Both dominating and dominated groups lived in specific social circumstances that conditioned them to develop and 'prefer' lifestyles that are homologous with these positions. Legitimate cultural practices such as museum attendance, theater going, recreational reading of 'the classics', the development of interests in cinematic genres and directorial styles, foreign travel as well as avant-garde music turned out to be largely reserved to the dominant class. Bourdieu illustrates the further variants of taste in a range of binary oppositions: where the vulgar taste emphasizes the practical function, the elaborate taste stresses its aesthetic form; if the ordinary taste is led by the quantity of a cultural item, the pure taste favours quality; whereas in popular taste matter and substance dominate, the kind or manner of consumption come to foreground in bourgeois culture. Since the latter is the most 
distanced from the sphere of material necessity it appears to be built upon an ethos of facility, casualness, freedom and 'ease':

'Ease is so universally approved only because it represents the most visible assertion of freedom from the constraints which dominate ordinary people, the most indisputable affirmation of capital as the capacity to satisfy the demands of biological nature or the authority which entitles one to ignore them.' (Bourdieu 1984: 253)

The legitimate taste stands in sharp contrast to petty-bourgeois taste that is characterized by a 'concern for conformity which induces an anxious quest for authorities and models of conduct,' an 'insatiable thirst for rules of conduct which subjects the whole of life to a rigorous discipline', asceticism and a 'propensity to accumulation in all its forms.' (Bourdieu, 1984: 331) Rigour and discipline, on the one hand, freedom and ease, on the other, appear to originate from natural dispositions just as the working class's 'preference' for necessity and function. Having little capital, peasants and unqualified workers must be constantly concerned with the practicalities of material existence. $^{7}$

Cultural fields resemble other fields in that their rule of the game reflect power relations within which above all 'cultural capital', both in its institutionalized and embodied forms, serves as currency to classify the actors and their practices into a hierarchy of lifestyles. Yet cultural or symbolic goods differ from material goods in that one can consume them only to the extent that one apprehends their meaning. And this is possible only if actors 'already possess the necessary

\footnotetext{
${ }^{7}$ The most recent large-scale study on cultural practices using a Bourdieusian methodology largely confirmed Bourdieu's original results, albeit with important qualifications (Bennet et al., 2009). First, a legitimate culture continues to structure lifestyles, with volume and structure of economic and cultural capital explaining most of the cultural differences. Yet, secondly, this distribution of capital differentiates some fields more than others, with music being the most marked by opposition of taste, while sport, film and television featured weaker patterns. Third, alongside class, age and gender play greater roles in the shaping of cultural practices than considered in Bourdieu's original study.
} 
schemes of appreciation and understanding.' (Brubaker, 1985: 757) However, this capability is unequally distributed across social space. Class-specific socialization in family and the school system ensures that a 'disproportional number of those attaining high educational credentials will have a relationship of comfortable familiarity with legitimate culture' (Allen and Anderson, 1974: 72) - an appropriation act that is rarely reflected upon. This process of 'cultivation' through which cultural capital is accumulated begins in the family and takes the form of an investment of money and time (either of hired specialists or the parents' own time), which, if successful, returns dividends in school, university, social contacts and the marriage and job markets. Hence, practices that objectively follow naked class interest come across as selfless pursuit of commonly recognized symbolic goods, making winners appear not as holders of power but as gifted individuals with superior tastes. Bourdieu and Passeron (1977: 6) refer to the imposition of the life-style of the dominant class as the legitimate taste as an act of 'symbolic violence' - arbitrary, hidden from view and therefore accepted by the dominated themselves.

In essence, in the sphere of consumption social differences appear as natural ones because the legitimate taste is the farthest from the sphere of necessity. Due to this objective distance it appears to be being built upon an 'ethos of ease', of 'casualness, grace, facility, elegance, freedom, in a word, naturalness." (Bourdieu, 1984: 339) As a corollary, purchasing things for individual consumption is not in the first place about the goods themselves, but rather about the symbolic message that the act of purchase conveys. Both the acquisition and possession of use values symbolize much of our social standing in society and of our identity and sense of belonging. However, if the rate of production of new, fashionable and desirable goods is high and accelerating, continuous efforts must be made by all social agents to reestablish or improve their original social position and to distance themselves from other people. Yet there is always 
the danger of vulgarization, of devaluation through the emulation and generalization of certain cultural practices, which once held the aura of legitimacy. This accelerates the never-ending cycle of definitions of taste by the avant-garde and of keep-up strategies by the mainstream. This cycle plays into the hands of various culture industries, but contradicts the principal reproductive needs of the Earth as an ecological system since - all other things being equal increases in commodified consumption are accompanied by greater matter and energy throughputs.

\section{CONCLUSION AND DISCUSSION}

This paper theoretically analyzed the naturalization of economic growth in relation to both production and consumption relations. Marx's Critique of Political Economy not only provides a theory of the structural imperative of capitalist economies to expand in scale and grow in monetary terms, it also demonstrates how specifically capitalist economic categories and social relations are reflected in the actors' minds. The historically specific mode of transfer of surplus labour is hidden by what we referred to as a stepladder of mystifications as a result of which capitalism appears as the natural and eternal way of organizing 'the' economy. Due to the wage form all labour seems to be paid so that profit in its various forms must result from other sources than surplus labour. The 'topsy-turvy world' of the 'trinitary form', where wage labour contributes to societal wealth on the same footing and in functional harmony with profits and rents, is the structural, albeit hidden, background for the widespread idea that economic growth is beneficial to all - including to those who contribute to it through work. The corollary is the illusion that the more one works the greater one's share in societal wealth will be. In fact, from the common perspective of circulation and market transactions, own work seems to be the only possibility of becoming a commodity owner in the first place. Core societal values and orientations such as 'achievement', 'upward mobility' and 'social position as result of own 
work and merits', which are of crucial significance for the hegemony and maintenance of the growth paradigm, turn out to be socially valid forms of thought that result from the objective inversions inherent to the capitalist production and accumulation process.

The consideration of the Regulation approach and Bourdieu led to the result that the conversion of specifically social and economic categories into features of things and nature finds its continuation and completion in consumption and culture. Bourdieu theoretically and empirically demonstrates correspondence between positions in social space (especially class positions) and individual consumption. The cultural sphere is a site of symbolic struggles over the societal acceptability of lifestyles in which the dominant class manages to maintain a hierarchy of cultural forms that subjects all consumptive acts to the legitimate taste (its own). This classification process is 'objective' and effective insofar it operates largely independently of the (manipulative) intentions of dominant groups who are themselves subject to the distortion of social into natural forms. While members of the middle and working classes may eschew legitimate cultural practices or regard them with suspicion and disdain, the position of the dominant class at the pinnacle of the cultural hierarchy goes normally unchallenged, because it appears to be built upon ease, casualness and natural superiority. What Hirsch (1976) called the competition for 'positional goods' is mediated through a genuinely social logic that Bourdieu refers to as 'distinction', perceived as natural differences.

The result of the naturalization of the specifically capitalist character of production and consumption relations is that economic growth appears to be the ideal breeding ground for upward mobility and progress and in everyone's interest. With regard to production relations a strong work ethic seems to be a worthwhile and rational individual strategy, while in 
consumption growth guarantees the creation of ever new generations of consumer articles which are the material basis for individual distinction. And since, as both Marx and Bourdieu demonstrate, capitalist production and consumption relations tend to be perceived as natural interactions of autonomous and rational market subjects, we have arrived at an adequate understanding of the growth imperative's deep embeddedness in core structures of contemporary society. With Bourdieu (Bourdieu et al., 2002: 182), who used the example of neoliberalism, we may compare the hegemonic power of the growth imperative to that of the Catholic doxa of the Middle Ages, since it serves as a kind of pensée unique providing natural solutions for all kinds of social and ecological issues. Yet the impact of corresponding thinktanks, which relentlessly preach and amplify the growth paradigm, on policymakers and the wider society could only become so efficient, since there is a certain readiness for collaboration or a degree of practical consent on the part of those who are exposed to power and symbolical violence. In fact, this submission of the dominated goes even further than normally emphasized in the Marxian tradition. Social structures such as the growth imperative are inscribed not only in the 'ideas' and the 'minds' of the dominated, in their mental representations, but also in their bodies, in their 'schemes of perception and dispositions (to respect, admire, love, etc.), in other words, beliefs ...' (Bourdieu, 2000: 171).

Conversely, the systematic consideration of Marx, the Regulation approach and Bourdieu in growth-critical scholarship helps define the structural conditions that facilitate the overcoming of the growth imperative via a 'social-ecological transformation' (Brand, 2016). One would succumb to 'scholastic fallacy' when expecting heterodox practice and social change to be accomplished by the 'raising of consciousness' alone. Though the potential role of activism in bringing about alternative discourse and practice should not be underestimated, Bourdieu (1991: 34) refers to a second precondition for this to occur, which is perhaps even more crucial. 
'Heterodox discourse' such as that of degrowth has 'more chance of appearing in overt or masked periods of crisis affecting either entire societies or certain classes, that is, in periods, where the economic or morphological transformations of such or such a part of society determine the collapse, weakening, or obsolescence of traditions or of symbolic systems that provided the principles of their worldview and way of life.' The chance of alternative ways of thinking and acting becoming hegemonic depends on the existence of a crisis and transformation of the 'objective' economic, political and cultural structures of society and the corresponding symbolic systems. Any intellectual critique of the growth imperative is only effective to the extent to which it is able to build upon such crisis.

\section{ACKNOWLEDGEMENTS}

An earlier draft of this paper was presented at the Fifth International Degrowth Conference in Budapest. I would like to thank Kate Soper, Hubert Buch-Hansen, Eric Brandstedt for very constructive comments on an earlier draft. This research benefited from the funding of FORTE (Sustainable Welfare and Eco-social Policies, 2016-07284) and FORMAS (The New Urban Challenge? Models of Sustainable Welfare in Swedish Metropolitan Cities, 201600340).

\section{REFERENCES}

Aglietta, M. 1987. A Theory of Capitalist Regulation: The US Experience. London: Verso.

Allen, D.E. and P.F. Anderson. 1974. 'Bourdieu's Theory of Consumer Taste Formation'. Advances in Consumer Research 21: 70-74.

Alvarez Lozano, L.J. 2012. 'Withdrawal from growth: The environmental challenge for twentyfirst century socialism'. International Critical Thought 2 (1): 71-82.

Asara, V., E. Profumi and G. Kallis. 2013. 'Degrowth, democracy and autonomy.' Environmental Values 22: 217-239.

Bennett, T., M. Savate, E. Silva, A. Warde, M. Gayo-Cal, and D. Wright. 2010. Culture, Class, Distinction. London: Routledge. 
Bourdieu, P. 1984. Distinction: A Social Critique of Judgement and Taste. Cambridge: Harvard University Press.

Bourdieu, P. 1986. 'The forms of capital'. In J.G. Richardson (ed), Handbook of Theory and Research in the Sociology of Education, pp. 241-258. New York: Greenwood Press.

Bourdieu, P. and J.-C. Passeron. 1977. Reproduction in Education, Society and Culture. London: Sage.

Bourdieu, P. 1991. 'Genesis and structure of the religious field'. Comparative Social Research 13: $1-44$.

Bourdieu, P. 2000. Pascalian Meditations. Cambridge: Polity.

Bourdieu, P. 2005. The Social Structures of the Economy. Cambridge: Polity.

Bourdieu, P. et al. 2002. The Weight of the World. Social Suffering in Contemporary Society. Cambridge: Polity.

Boyer, R. 2008. 'Pierre Bourdieu, a Theoretician of Change? The View from Régulation Theory', in A. Ebner and N. Beck (eds), The Institutions of the Market: Organizations, Social Systems, and Governance, pp. 348-398. Oxford: Oxford University Press.

Boyer R. and Y. Saillard, eds. 2002. Régulation Theory. The State of the Art. London: Taylor \& Francis.

Brand, U. 2016. 'How to get out of the multiple crisis? Contours of a critical theory of socialecological transformation'. Environmental Values 25: 503-525.

Brand, U. and M. Wissen 2015. 'Strategies of a Green Economy, Contours of a Green Capitalism', in: K. van der Pijl (ed) The International Political Economy of Production. Cheltenham: Edward Elgar (508-523).

Brubaker, R. 1985. 'Rethinking classical theory. The sociological vision of Pierre Bourdieu'. Theory and Society 14 (6): 745-775. 
Büchs, M. and M. Koch 2017. Postgrowth and Wellbeing: Challenges to Sustainable Welfare. Basingstoke: Palgrave Macmillan.

Burkett, P. 1999. Marx and Nature. A Red and Green Perspective. New York: St. Martin's Press.

Burkett, P. 2009. Marxism and Ecological Economics: Toward a Red and Green Political Economy. Leiden: Brill.

Clark, B. and R. York. 2005. 'Carbon metabolism: Global capitalism, climate change, and the biospheric rift.' Theory and Society 34 (4): 391-428.

Collard, R.-C. and J. Demsey 2017. 'Capitalist natures in five orientations.' Capitalism, Nature, Socialism 28 (1): 78-91.

Dale, G. 2012a. 'The growth paradigm: A critique'. International Socialism No. 134. Available online at http://isj.org.uk/the-growth-paradigm-a-critique/.

Dale, G. 2012b. 'Critiques of growth in classical political economy: Mill's stationary state and a Marxian response'. New Political Economy 18 (3): 431-457.

Daly, H.E. 1972. 'In defense of a steady-state economy'. American Journal of Agricultural Economy 54: 945-954.

D’Alisa, G., F. Demaria, and G. Kallis, eds. 2014. Degrowth: A Vocabulary for a New Era. London: Routledge.

Ferguson, P. 2016. 'Liberalism and economic growth: A theoretical explanation.' Environmental Values 25: 593-619.

Foster, J.B. 2000. Marx’s Ecology. New York: Monthly Review Press.

Fraser, N. 2014. 'Behind Marx’s hidden abode.' New Left Review 86: 55-74.

Fritz, M. and M. Koch. 2016. 'Economic development and prosperity patterns around the world: Structural challenges for a global steady-state economy.' Global Environmental Change 38: 41-48. 
Gramsci, A. 1971. Selections from the Prison Notebooks. New York: International Publishers.

Harvey, D. 1990. The Condition of Postmodernity: An Enquiry into the Origins of Cultural Change. Cambridge: Blackwell.

Herkommer, S. 1985. Einführung Ideologie. Hamburg: VSA.

Herkommer, S. 2004. Metamorphosen der Ideologie. Zur Analyse des Neoliberalismus durch Pierre Bourdieu und aus marxistischer Perspektive. Hamburg: VSA.

Hirsch, F. 1976. The Social Limits to Growth. Cambridge, MA: Harvard University Press.

Jevons, W.S. 1865. The Coal Question. An Inquiry Concerning the Progress of the Nation, and the Probable Exhaustion of Our Coal-Mines. London: Macmillan and Co.

Jonas, M. and B. Littig 2015. 'Sustainable practices', in Wright, J.D. (ed) International Encyclopedia of the Social \& Behavioral Sciences. Oxford: Elsevier (pp. 834-838).

Kenney-Lazar, M. and K. Kay 2017. 'Introduction: Value in capitalist natures.' Capitalism, Nature, Socialism 28 (1): 33-38.

Koch, M. 1998. Vom Strukturwandel einer Klassengesellschaft. Theoretische Diskussion und empirische Analyse. Münster: Westfälisches Dampfboot.

Koch, M. 2006. 'Pierre Bourdieu as a sociologist of the economy and critic of "globalization".' International Journal of Contemporary Sociology 43 (1): 327-346.

Koch, M. 2012. Capitalism and Climate Change. Theoretical Discussion, Historical Development and Policy Responses. Basingstoke: Palgrave Macmillan.

Koch, M. 2015. 'Climate change, capitalism and degrowth trajectories of a global steady-state economy'. International Critical Thought 5 (4): 439-452.

Koch, M. and O. Mont, eds. 2016. Sustainability and the Political Economy of Welfare. London: Routledge.

Maddison, A. 2007. Contours of the World Economy, 1-2030 AD, Oxford: Oxford University 
Marx, K. 1973. Grundrisse. Foundations of the Critique of Political Economy. Harmondsworth: Penguin.

Marx, K. 1990. Capital: A Critique of Political Economy. Vol. 1. London: Penguin Classics.

Marx, K. 2006. Capital: A Critique of Political Economy. Vol. 3. London: Penguin Classics.

Mies, M. 1998. Patriarchy and Accumulation on a World Scale. London: Zed Books.

Moore, J. 2015. Capitalism in the Web of Life. Ecology and the Accumulation of Capital. London: Verso.

O’Connor, J. 1998. Natural Causes. Essays in Ecological Marxism. New York: Guildford.

Pichler, M., A. Schaffartzik, H. Haberl and C. Görg 2017. 'Drivers of society-nature relations in the Anthropocene and their implications for sustainability transformations.' Current Opinion in Environmental Sustainability 26: 32-36.

Rehmann, J. 2007. 'Ideology theory.' Historical Materialism 15: 211-239.

Rehmann, J. 2015. 'Ideology-Critique with the conceptual hinterland of a theory of the ideological.' Critical Sociology 41 (3): 433-448.

Schmelzer, M. (2016) The Hegemony of Growth. The OECD and the Making of the Economic Growth Paradigm. Cambridge: Cambridge University Press.

Shove, E. 2010. 'Beyond the ABC: Climate change policy and theories of social change.' Environment and Planning A 42: 1273-1285.

Spash, C.L. 2016. 'Socio-ecological transformation and the individual.' Environmental Values 25 (3): $253-258$.

Spash, C.L., ed. 2017. Routledge Handbook of Ecological Economics: Nature and Society. London: Routledge.

Steffen, W., K. Richardson, J. Rockström, S.E. Cornell, I. Fetzer et al. 2015. 'Planetary boundaries: guiding human development on a changing planet.' Science 347: 1259855. 